○RDINES MILITARES

COLLOQUIA TORUNENSIA HISTORICA

Yearbook for the Study of the Military Orders

ISSN (print) 0867-2008 / ISSN (online) 2391-7512

DOI: http://dx.doi.org/10.12775/OM.2015.006

pp. $123-144$

Johannes A. Mol

Fryske Akademy / Universiteit Leiden

Post Box 54

8900 AB Leeuwarden

Netherlands

hmol@fryske-akademy.nl

\title{
THE KNIGHT BROTHERS FROM THE LOW COUNTRIES IN THE CONFLICT BETWEEN THE WESTPHALIANS AND THE RHINELANDERS IN THE LIVONIAN BRANCH OF THE TEUTONIC ORDER
}

\section{KEYWORDS}

Teutonic Order; Livonia; internal conflicts; $5^{\text {th }}$ century; medieval prosopography; careers

$\mathrm{P}$ rosopographical research is a rewarding but time and energy consuming kind of study. As for the military orders, the challenge may be too big when datasets on thousands of persons have to be built, like in the case of the Templars at the time of the trials or the Teutonic knights in early fifteenth century Prussia. About twenty-five years ago however, a serious collaboration project has been carried out to gather as much information as possible on the careers and origin of the somewhat smaller population of the Livonian knights of the Teutonic Order. Lutz Fenske and Klaus Militzer, who had the lead, brought a group of eight specialists together to produce a catalogue of Ritterbrüder which could 
serve as a point of departure for further research. ${ }^{1}$ In an thorough introduction, Militzer already succeeded in sketching a general but rather sharp picture of the slowly changing background of the knights, by classifying, counting and weighing the gathered information. ${ }^{2}$ Furthermore, Sonja Neitmann, who investigated the for Livonia important recruitment area of Westphalia, elaborated the data for the county of Mark into a solid dissertation. ${ }^{3}$ It was published in the same year as the catalogue, in 1993.

As I was among the correspondents - my task was to treat the brethren from the Low Countries - there always has been the urge for me to analyse whether or not the 'Dutch' men constituted a special group within the larger one. The central question then is how the brethren from the Netherlands - being neither clear cut Westphalians or Rhinelanders at first sight - fared in the fifteenth century strife for predominance within Livonia that rose between those two regional party groups. This conflict, pitting the Westphalian and Rhineland brothers against each other, was primarily about the control of the most important offices, though is it indirectly also concerned the leadership and political course of the Order State. One of the reasons to tackle the question on the Dutch participation is that the basic data in the catalogue concerning the brethren from the Low Countries suggest that their number did rapidly decline after I 450 whereas they had been fairly well represented around I 430 , counting for around one sixth of all Order's knights. Taking the how and why of this tendency as a point of departure, my paper will thus be on the party inclination of the Dutch in the Livonian branch of the Teutonic Order. As for my interpretations, I am leaning heavily on the findings of prof. Militzer and dr. Neitmann.

Before getting in medias res, we need some introductory facts on the Livonian brethren in general and the interest for the Teutonic Order in the medieval Low Countries.

1 Ritterbrüder im livländischen Zweig des Deutschen Ordens, ed. L. Fenske, K. Militzer (Quellen und Studien zur Baltischen Geschichte 12), Köln-Weimar-Wien 1993.

2 K. Militzer, Die Ritterbrüder im livländischen Zweig des Deutschen Ordens. Eine Einfübrung in die Möglichkeiten und Grenzen der Auswertung des Ritterbruderkatalogs, in: Ritterbrüder im livländischen Zweig des Deutschen Ordens (as n. 1), pp. 11-70.

3 S. Neitmann, Von der Grafschaft Mark nach Livland. Ritterbrüder aus Westfalen im livländischen Deutschen Orden (Veröffentlichungen aus den Archiven Preussischer Kulturbesitz, Beiheft 3), Köln-Weimar-Wien 1993. 


\section{The Livonian BRAnCh OF the Teutonic ORder}

To understand the recruitment pattern of the Livonian knights, it is important to know that after the takeover of the Sword Brothers the Teutonic Order in Livonia gradually evolved from a side branch, dependent on the central leadership in Prussia centre, to a more or less autonomous unit pursuing its own policy. ${ }^{4}$ This had consequences for the mobility of its members. Whereas in the thirteenth and early fourteenth centuries the brethren could be moved to and fro between Livonia, Prussia and the bailiwicks, with masters and commanders holding office for only short terms, in the course of the fourteenth century, they now stayed within Livonia. It also meant that the Order's administration in Livonia came to organise its own recruitment, apart from Prussia. As for the choice of the regions from where novices were called in, little changed however. Though the Low German element, which had dominated in the time of the Sword Brothers, had diminished slightly through the early dynamic transfer and promotion policy of the Teutonic Order, the lines between Livonia and Low Germany, including Westphalia, remained fairly strong. The Master of Livonia, who was now appointed by the Grand Master for life, was inclined to let most of his new men come from Low Germany, often mainly from his region of birth. Families there who favoured the Order, knew that when one of their members decided to enter the Livonian branch, he would have a career only there, remaining a brother of this branch until death. Because of this, Westphalia, the Rhineland and the contiguous territories in the west, north and east constituted the regional basis for recruitment before I 400. According to Militzer, forty per cent of all commanders, marshals and masters originated in Westphalia, whilst the number of Rhinelanders reached 25 to 30 per cent. ${ }^{5}$

Provided they enjoyed the right patronage, ambitious and able knights could reach attractive positions of power. In the course of time the Order-land had been divided into about 30 separate territories having one or two castles with a convent as their centre, which had to be administered by knight brothers. ${ }^{6}$ The Master of Livonia himself reigned over the central territory surrounding Wenden. The

4 For a recent analysis of the developments within the Livonian branch of the Teutonic Order, see B. Jähnig, Verfassung und Verwaltung des Deutschen Ordens und seiner Herrschaft in Livland (Schriften der Baltischen Historischen Kommission 16), Berlin 2011.

5 Militzer (as n. 2), pp. 11-17.

6 F. Benninghoven, Die Burgen als Grundpfeiler des spätmittelalterlichen Wehrwesens im preußisch livländischen Deutschordensstaat, in: Die Burgen im Deutschen Sprachraum. Ihre rechts- und verfassungsgeschichtliche Bedeutung (part 1), ed. H. Patze (Vorträge und Forschungen XIX/1), Sigmaringen 1976, pp. 565-600. 
number two man in the hierarchy, the land marshal, controlled the nearby district of Segewold. The rule of other areas was handed over to commanders and socalled Vögte. Five of these 'Gebietiger', the Vogt of Jerwen and the commanders of Reval, Fellin, Goldingen and (Livonian) Marienburg, together with the marshal composed the so-called 'Innere Rat' (or Inner Council), whose advice the Master was increasingly bound to since $c$. I 400. These major preceptors, together with the other high office holders, composed the foundation on which the Teutonic Order's system of posts or offices rested. Aided by a number of fellow brothers in house-offices they led the remaining, office-less brothers which manned the local Order convents as a garrison. Furthermore, they were responsible for the agrarian business and trade enterprises that the Order exploited for its own benefit with the aid of service personnel. They held legal court, collected tithes and in case of war commanded the local vassals and levied peasants.

One should not overestimate the size of the Livonian knight-brotherhood.7 Its strength is estimated as averaging $400 \mathrm{men}$ in the fourteenth century. For the year I $45 \mathrm{I}$, on the basis of a visitation report, total membership can be calculated to 197 knight brothers plus 43 priests and 27 servant brothers. The much more numerous Prussian branch of the Order would around I 400 and I 450 have counted 700 and 400 knight brothers respectively. So after c. I 400 a strong decline manifested itself in both branches, due to - among other reasons- a gradual increase in demands with regards to clothing, life support and such.

\section{NUMBERS AND AREAS OF ORIGIN OF THE BROTHERS FROM THE LOW COUNTRIES}

In the entire period of 1202 to 1562 some 1.006 names are known for the Livonian branch of the Order. ${ }^{8}$ For only 723 their family or region of birth could be established with some certainty. Most are transmitted in Livonian charters and acts. This number can only have been a fraction of all the knights that once belonged to the Livonian branch. If one takes, as Militzer did, an estimate of an average yearly occupation of $150-200$ in the thirteenth century, 350-400 in the fourteenth, and again 200 in the fifteenth and sixteenth centuries as their starting point, and if one multiplies these figures by a factor of 10 - presuming that due to the high rate of

7 F. Benninghoven, Zur Zahl und Standortverteilung der Brüder des Deutschen Ordens in den Balleien um 1400, Preußenland 26 (1988), pp. 1-20; Militzer (as n. 2), pp. 13-16; Neitmann (as n. 3), pp. 37-38; Jähnig, (as n. 4), pp. 127-134.

8 Militzer (as n. 2), p. 18 sqq. 
attrition, in campaigns and otherwise, a knight brother only stayed alive for ten years -, then one would arrive at a grand total of approximately 8.000 brothers. This would imply that less than $10 \%$ of these has been traced.

Per period the number of 723 named knight brothers can be divided - the first two periods set apart - in I 7 for the time span between I 309 and I 410 (heydays, until the battle at Tannenberg); 427 for the period I 4 IO-I 536 (from Tannenberg until the death of Wolter von Plettenberg) and 134 for the last period until the collapse of the Livonian Order in I 562 . It will be no surprise that the largest number relates to the fifteenth and sixteenth centuries. Of exceptional importance is therefore the visitation report from I 45 I, which contains the names of all knight brothers per castle. Without it, tallying and weighing the data would be much less interesting, because it is nearly the only source wherein brothers without an office are identified by name and surname. The other remaining fragments always concern men who rose in the hierarchy, quitting anonymity when they are named as issuer, consignor, witness, and the like. If there was a connection between descent and career, this can be shown only by analysing this report.

For an extrapolation of the areas of origin, the most refined politico-geographical classification can be used for the late Middle Ages. For the sake of oversight, however, I will confine myself to a global division covering: I Westphalia; 2 the German Rhineland; 3 the Low Countries; and 4 the rest, consisting of South-Germany, eastern Middle-Germany, the western Baltic coast from Holstein to Pomerania. The Low Countries encompass: the bishopric of Utrecht, which for its secular territory was divided into the Nedersticht and Oversticht (encompassing the nowadays provinces of Drenthe and Overijssel), the duchies of Guelders and Brabant ${ }^{9}$, and the counties of Limburg, Loon and Valkenburg.

At face value, a percentage of I I \% for the Low Countries might not seem like much. However, when we weigh it in relation to the enormous size of the Holy Roman Empire as a potential recruitment area, it cannot but be named considerable. As will be shown, the Low Countries segment can be more closely confined to its eastern part, to wit the territories on either side of the IJssel, Rhine and Meuse. Comparing that area's data with those of other major areas of origin in the Holy Roman Empire then, we have to conclude that it concerns the second most important recruitment area of the Livonian branch of the Order.

9 Militzer also accounts the 12 identifiable brothers from the duchy of Cleves to the Lower Rhine-area. Seen from a landscape point of view, this is tenable, but since I am trying to analyze the recruitment of the brethren in the territories of the Low Countries, to which Cleves never has been reckoned, I prefer to classify it here as a part of the Rhineland. In my calculation however, the brothers from the region around Geldern (near Jülich) however are seen as men from the Netherlands, because Geldern belonged to the duchy of Guelders. 
Dissecting the number of 77 for the Low Countries as a whole, and adding to that a subdivision per period, the following image arises:

\begin{tabular}{|c|c|c|c|c|}
\hline Region & $<1400$ & $1400-1500$ & $1500-1562$ & Total \\
\hline Utrecht Nedersticht & & 5 & & 5 \\
\hline Utrecht Oversticht & 1 & 18 & 1 & 20 \\
\hline Guelders (ex. Overkwartier) & 2 & 21 & 8 & 31 \\
\hline Guelders (Overkwartier) & & 1 & 9 & 10 \\
\hline Brabant, Limburg, Valkenburg & & 6 & 4 & 10 \\
\hline Other areas & & & 1 & 1 \\
\hline Total & 3 & 51 & 23 & 77 \\
\hline
\end{tabular}

The first thing of note in this table is that the Southern Netherlands, where the bailiwick of Biesen had most of its houses, are under-represented. It appears that this order's district only incidentally sent people to Livonia. After the loss of the Holy Land its attention and support were more claimed by the Prussian branch. ${ }^{10}$ Also noticeable is that the coastal districts of Zeeland, Holland and Frisia are almost completely excluded. This is odd because the bailiwick of Utrecht had many settlements in these areas. And we know that the bailiwick itself recruited many of its brothers there. ${ }^{11}$ So, it has to be concluded that the recruitment area of the bailiwick did not completely coincide with that of the Livonian branch of the Order. If individual preceptories functioned as recruitment centres, this then can only have been the case for Ootmarsum, Doesburg, Rhenen and Tiel. The house of Dieren fits this frame in a geographical sense, but it only was incorporated into to bailiwick Utrecht in I 434 via the bailiwick of Biesen, after it had been part of the bailiwick of Koblenz until I 420, and had stood as such directly under the

10 The Biesen land commander Iwan van Cortenbach for instance has been several times in Prussia with some of his knight brothers to support the grandmaster in his campaigns against Poland: Regesta Historico-Diplomatica Ordinis S. Mariae Theutonicorum 1198-1525, vols. 1-2, ed. E. Joachim, W. Hubatsch, Göttingen 1948-1973, hier vol. 2, passim. In 1416/1417 the bailiwick of Utrecht contributed 700 rhine-guilders to one of his expeditions (de Prusschenreyse die die lantcommendeur van den Byessen had): Archief van de Ridderlijke Duitsche Orde balije van Utrecht, Utrecht [further as: ARDOU], nr. 335, rek. 1416-1417, f. 2v.

11 R. Stapel, "Onder dese ridderen zijn oec papen". Priesterbroeders in de balije Utrecht van de Duitse Orde (1350-1600), Jaarboek voor Middeleeuwse Geschiedenis 11 (2008), pp. 205-248, 221-227. 
rule of the Prussian branch..$^{12}$ Here it should also be noted that the preceptory of Ootmarsum was disputed for a long time between the bailiwick of Utrecht and the bailiwick of Westphalia, the latter of which finally acquired it in 1452 . Which, all in all, suggests that the early recruitment of Dutch knight brothers for Livonia was not just organised and stimulated through Utrecht, but also through Münster (as the centre of the bailiwick of Westphalia).

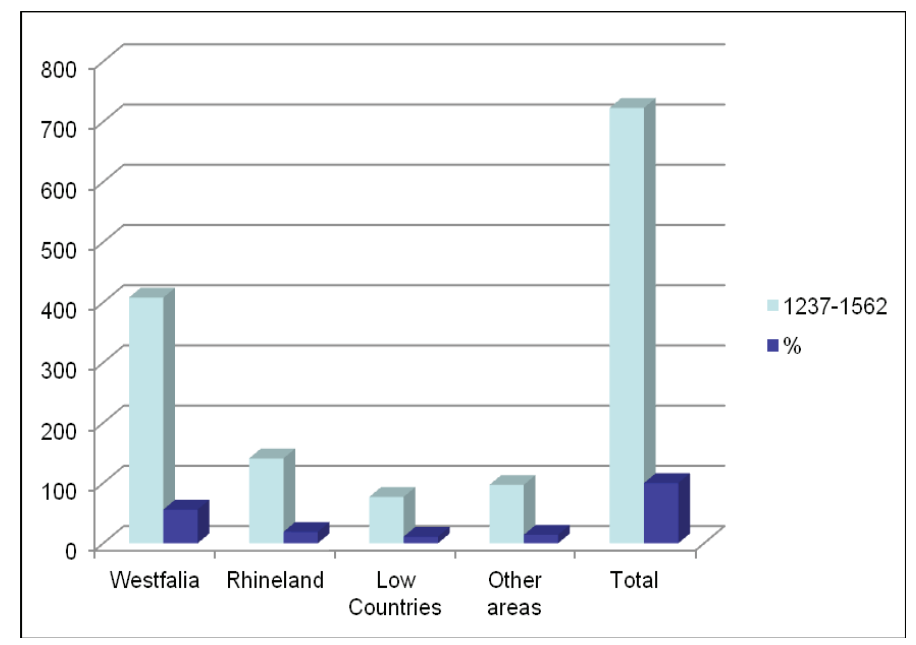

From the period prior to 1400 , only three names of Livonian brothers from the Low Countries are handed down. But these three occupied important posts. Johan of Hoenhorst for instance was Vogt of Jerwen in I 322 ; in that year he was one of the candidates for the office of Master of Livonia but he was passed by and returned to Utrecht to function as land commander there in the period of 1325-1344. His career appears to have been typical for the early fourteenth century, when members of the Order could still be easily moved and promoted from area to area by the central leadership. He and the other ones will certainly have tried to use the prestige of their office to raise interest amongst family members and fellow countrymen for induction into the Livonian branch of the Order via the Teutonic house in Utrecht. ${ }^{13}$

12 The fortunes of the Teutonic Order's houses of Dieren and Ootmarsum are treated in Archieven der Ridderlijke Duitsche Orde, balie van Utrecht, 2 vols, ed. J. J. de Geer tot Oudegein, Utrecht 1871, hier vol. I, p. xxxviii ff.

13 There is at least one indication that the bailiwick of Utrecht maintained close relations with Livonia in the second half of the fourteenth century. In one of the few surviving accounts for 
It can furthermore be made out from table 2 that the Low Countries were much better represented in Livonia in the fifteenth century than in the previous period. Many brothers originated from the Utrecht Oversticht and the four quarters of Guelders in particular. In the sixteenth century their numbers are shown to have halved again. As for the fifteenth century, the number of 3 I brothers for the year I 45 I amounts to a clear indication of the relatively large share of brothers from the Low Countries within the whole. As I have underlined already in my introduction: to the 197 knight brothers populating the Livonian convents, this means a percentage of 16 or roughly one in six. ${ }^{14}$

Lastly, when comparing the duchy of Guelders and the prince-bishopric of Utrecht to one another as two most important feudal areas of origin, it is remarkable that Utrecht no longer supplied brothers for the Livonian Order around I 500 . Closer examination shows that this date can be moved back in time by a few decades. Of the 23 fifteenth-century Livonia-goers from the Nedersticht and the Oversticht, there is but one who started his career in the second half of the fifteenth-century. ${ }^{15}$ The others are only mentioned in $145 \mathrm{I}$ or earlier than that in various posts. Only Willem of Hinderstein, Vogt of the prestigious preceptory of Doblen in I 45 I, held office in Livonia afterwards. In I 460 he turns out to reside as an office-less knight brother in Utrecht. Why did he return and why did after him barely anyone from the Utrecht territories made a career in Livonia?

\section{RECRUITMENT CAMPAIGNS IN THE BAILIWICK OF UTRECHT}

To find an answer to that question, it is useful to present some data on the recruitment in the bailiwick of Utrecht. A charter from 1422 wherein Sweder Cobbing, land commander of Utrecht, gives a statement on the monies he had cashed in I 4 I I as land commander of Westphalia in recruiting knight brothers from Utrecht, proves quite insightful. ${ }^{16}$ The direct lead-up to that action was a request by the

that period, on the year 1379 , is noticed that spices (crude) have been given to 'die Lieflanders' (with which doubtlessly some Livonia-goers are designated) for a sum of 9 pounds and 10 st.: ARDOU, nr. 646.

14 Neitmann (as n. 3), p. 653. Therewith, the men of the Low Countries had a larger share in the Livonian branch of the Order than the 'real' Rijnlanders, of whom 22 knight brothers were counted $(=11 \%)$.

15 This concerns Egbert van den Berge, who probably was the son of a patrician from Deventer. We encounter him for the first time in the sources in 1476 as assistant (Kompan) of the Vogt of Soneburg on the isle of Wiek. His name is mentioned for the last time in 1514, when he was Vogt of Bauske, a castle in southern Latvia near the border with Lithuania.

16 Archieven (as n. 12), vol. II, nr. 345. 
Master of Livonia, Conrad von Vietinghoff, for Cobbing to find new brothers for Livonia in his surroundings and send these to Lübeck. It can be no coincidence that this was done in the year after Tannenberg. Although no Livonian brothers died in that battle - the Master of Livonia had been unable to reach the battlefield in time - Livonian troops took a decisive part in the re-conquest of the Prussian Order's areas, where a number of Livonian brothers met their end. ${ }^{17}$ Possibly the depleted Prussian ranks were then partly manned with Livonians, resulting in Livonia being tight on manpower.

It makes perfect sense that the Master turned to the Westphalian land commander. Vietinghoff was a Westphalian himself. Cobbing however had Utrecht interests as well: he had been commander of the house of Ootmarsum in I 406, which belonged to the bailiwick of Utrecht. ${ }^{18}$ For that reason, the focus of his campaign lay in the West. By his own account he rode to Utrecht on the advice of his successor at Ootmarsum, Floris van Jutfaas, because Jutfaas had some relatives there who were highly qualified to enter the Order. Cobbing stayed in Utrecht for a week at an inn ${ }^{19}$ and drafted at least three recruits. He demanded 60 rhine-guilders from each one for entry-fees and escorting-costs. However, he demanded nothing from other persons, who could not pay. In this manner he supposedly inducted 33 Livonia-goers into the Order, yielding him a total of 426 rhine-guilders. He sheltered some for over six weeks in 'his houses' (probably in Westphalia) until he had gathered all of them, so they could travel to Lübeck all at once.

A similar campaign must have been undertaken in the springtime of I 435 . In the accounts of the then land commander of Utrecht concerning the fiscal year I 434-I 435 there is mention of the costs incurred at 'Aernhem, to Doezeborch ende to Deventer' (quote) '[...] when I gave the habit to the knights which I sent with the distuingished men to Livonia. ${ }^{20}$ This then concerns not a Westphalian but a Utrecht action. It can be assumed that this initiative originated from the

17 E. Christiansen, The Northern Crusades. The Baltic and the Catholic frontier 1100-1525, London 1980, p. 219 sqq.

18 ARDOU, nr. 2298: account of the commandery of Ootmarsum on 1405/1406. Cobbing's family had properties and interests in the nearby lying county of Bentheim. See Tijdrekenkundig register op het oud provinciaal archief van Overijssel, 1225-1496, aanhangsel, ed. J. I. van Doorninck, Zwolle 1874, p. 252 (1427, May 12).

19 One would expect him to have been lodged in the Teutonic House in Utrecht. Did the brethren of the Utrecht bailiwick by then consider Cobbing's recruiting campaign to be a mere Westphalian affair, the costs of which the land commander of Westphalia had to cover himself?

20 '[...] doe ic die heren klede die ic voirt sande myt den gueden luden in Lyefflande': ARDOU, nr. 335, fol. 4r. In an earlier communication (Militzer (as n. 2), p. 63) I dated this activity at 1434. This is not very plausible however, when we realise that the financial year in the Utrecht bailiwick ran from September to September and the (undated) entry on the expenses for this 
many deaths amongst Livonian troops when a plague epidemic struck Lithuania in August I 433. The then-Master of Livonia, the 'Dutch' Cisse van den Rutenberg, had been forced by the circumstance to cancel a military expedition and succumbed himself to the disease on September i 5 after his return to Riga. It may have been the case that on his return he, exactly like Vietinghoff did before him in I 4 I I, requested his native bailiwick for new brothers, possibly via his high-placed confidant Matthias van Boningen - about whom more later. We can presume that a large part of the 3 I Dutch brothers mentioned in the visitation report from I 45 I had arrived in Livonia with these 1435 recruits.

We do not hear of such campaigns later on. The next communiqué dates from the year I 453 when the German Master authorized the Utrecht land commander Dirk van Enghuzen to send some rebellious brothers to Prussia and Livonia. ${ }^{21}$ Amongst these was his (blood) brother Jan, who had resided in the Livonian Marienburg in $145 \mathrm{I}$ as a knight brother but had returned in 1454 and stayed in Utrecht. This is evidenced by a charter from that year, which explicitly mentions matters of contention ('gebreke') between both brothers. These concerned the fees the land commander was to pay for a suit of armour and getting his brother of to Livonia again. Jan acknowledges that Dirk has fulfilled his commitments. He then, for his part, promises to meet the demands imposed upon him, the most important of which was that he would travel from Utrecht to Livonia, never to return!

It can be no coincidence that when Van Enghuzen's successor Johan van Haeften took office in 1456 , he pardoned the misdemeanour of all rebellious brothers by promising never again to expel brothers from the bailiwick to Prussia or Livonia. In these and later years, there apparently was a strong resistance to sending out individual brothers to the East. This remained so in the coming decades. In the sixteenth century, for office-less brothers a transfer to Livonia even seems to have functioned as a punishment. In I 55 I for instance, Peter van Hemert, fired from his post as commander of Bunne, was forced to promise that because of his disloyal and undisciplined life he would enter into the service of the Master of Livonia. ${ }^{22}$

action has been registered at the end of the account. In the winter period, there were usually no ships sailing to the Baltic.

21 Archieven (as n. 12), vol. II, nr. 366.

22 ARDOU, nr. 22 (letter from 1551). 


\section{A Utrecht network around Master Rutenberg}

This begs the question of why the brothers from the prince-bishopric of Utrecht refrained from participation in the Livonian branch of the Teutonic Order after the middle of the fifteenth century. Was the discrimination by the Westphalian leadership particularly strong towards them? To test that supposition, we need to trace whether the men from the Utrecht territories formed their own group, their own network within the Livonian branch, and if so, in how far this network pursued an anti-Westphalian policy.

The former issue is not that easy to study. Where in medieval social networks the foremost adhesive was kin, mutual familial connections are hard to trace for the Livonian brother-knights in particular. The knights in question often left at a young age for the East. They could not involve themselves with inheritances after their entry into the Order and consequently left few traces to track in family archives. Distance rather than membership was the premier contributing factor in slipping off the radar like this. After all, relatives who entered a religious community within their native region do appear often in private documents passed down in family archives. Livonia was far away, and the brothers there were rarely granted permission by their superiors to return home for family business. Within the few modern genealogies of the East-Dutch families, which should have included a large number of Livonian brothers going by their names, their actual presence is rare. For instance, the genealogy of the renowned Guelders ministeriales family Van Rossem does mention the knight brothers Johan, Gosen and Hendrik, who made their career in the bailiwick of Utrecht in the fifteenth and sixteenth centuries, but one searches in vain for two brother-knights by name of Gert, who are attested to have travelled to Livonia in $\mathrm{I} 442$ and between I 500 and I 523 respectively. ${ }^{23}$ An additional problem is that kinship relations via female sides of the family are almost never encountered because the name of the mother is only seldom to be retrieved. ${ }^{24}$

23 A. P. Van Schilfgaarde, Het adellijk geslacht Van Rossem, De Nederlandsche Leeuw 70 (1953), pp. 134-149. The same holds for the genealogies of (Huyn van) Amstenraide, Van Hoekelum and Van der Lawick.

24 Such a case is offered by the family relationship between Arnold Schenck von Nideggen, who helt the offices of house commander of Jerwel and Doblen 1527-1538 (and whose cousin Lutter Schenck von Nideggen entered the Order in 1553 in Mülheim a/d Möhne under the condition that he shoule ride to Livonia), and his great-uncle on the maternal side, Arnold van Schonauwen, who lived in the convent castle of Riga in 1451 as knight brother without an office: O. Merckens, Die Vorfahren der Irmgard von Schönau (Schoenauwen), Gemahlin des Johann Schenck von Nydeggen, Jülich-Bergische Geschichtsblätter 11 (1934), pp. 17-22, 43-48. 
We are therefore reliant on reports from Livonian sources in the majority of cases. For some persons however, there is noteworthy information available, especially in the case of the aforementioned Cisse van den Rutenberg. In all likelihood he was a son of the Salland ministerialis Dirk van den Rutenberg of Zalk and Mechteld van Heerde. ${ }^{25}$ The moment his name is first mentioned in written documents, in I $4 \mathrm{I} 3$ as commander of Mitau, it is clear that he is an important man in the Livonian Order leadership. Mitau was not considered amongst the 'Gebietiger'-positions, but nevertheless Rutenberg was asked by Grand Master Heinrich von Plauen to discuss the succession to Master Vietinghoff (who had died February I4, I 4 I3) together with Heinrich von der Recke. The latter was intended to represent the interests of the Westphalian brothers, Rutenberg apparently those of the Rhinelanders.

The contrasts between the Westphalians and the Rhinelanders had become quite divisive in the preceding decade. ${ }^{26}$ Where at first it concerned no more than a shifting dominance in patronage at promoting fellow brothers, after I 400 the dichotomy more and more touched on the political course of the Order state. On the whole, the Westphalian party chose the interests of the Livonian cities, whereas the Rhineland one tended to be loyal to the politics of the Grand Master c. q. Prussia, even when these could be disadvantageous to Livonia itself. The Prussian policies of the day had been aimed at preventing a structural alliance between Poland and Lithuania. This was done by deflecting Lithuanian attention and have the Lithuanians together with the Livonian brothers deal with the cities of Pskov and Novgorod. Which was not in the interest of Rigan merchants, however, who made good money trading with the Russians. In such cases the Westphalian party was prepared to set aside the Grand Master's desires if need be. In a certain sense the belated arrival of the Livonian brothers at Tannenberg can be seen as a consequence of this autonomous political course. The Livonian Master Vietinghoff had concluded a peace in $14 \mathrm{I} O$ at his own initiative with the Lithuanian Grand Duke Witold and had conceded to undertake no military actions for three months if war was declared. Even though the Livonian brothers did their best to help the Prussian branch reconquer its territory after Tannenberg, one can imagine that the central leadership in Prussia did not appreciate this political course after the event.

This became evident in I $4 \mathrm{I} 3$ during the aforementioned succession issue. Because of the numerical supremacy of the Westphalians amongst the brothers

25 The genealogical information on the Rutenberg family I owe to dr. O.D.J. Roemeling at Hardegarijp.

26 For the following, I am leaning mainly on S. Neitmann (as n. 3), p. 77 sqq. 
in office, Grand Master Heinrich von Plauen could only appoint a Westphalian, although he constrained this person to tight restrictions. The new man, Dietrich Torck, had to concede that he would not wage war on his own accord, or make peace by himself. Furthermore he had to promise to give the other 'tongues' of the Livonian branch of the Order so much leeway that at least half of the brothers would consist of non-Westphalians. Because Torck's promotion opened up the commandership of Fellin, a scramble for posts could be set in motion immediately, landing Rutenberg the Marienburg commandership. This gave Rutenberg a key position after I 4 I 3 , as the number two man of the Rhineland party and member of the 'Inner Council'.

Grand Master Heinrich von Plauen was deposed in the autumn of I $4 \mathrm{I} 3_{3}$ in Prussia. His successors Michael Küchmeister and Paul von Rusdorf did not change his political course with regards to Livonia, however. Küchmeister even went beyond that. After Torck's death, he did not elect a Westphalian to the position of Master of Livonia but a Rhinelander: Siegfried von Sponheim. Both Küchmeister and Rusdorf consciously strove for a 'Rhinelandization' of the Livonian branch to better control it. Sponheim let himself be used for that purpose and gave over the office of marshal and the commanderies of Fellin and Reval to fellow countrymen, landing leadership almost completely into Rhineland hands. It need not be said that Rutenberg profited from this. He moved on from the Marienburg to the commandery of Reval in 1423.

When Sponheim died the next year, the now experienced Rutenberg presented the most likely candidate to succeed him. During his reign, he did give the Westphalians more room than his predecessor, by supplying them with posts in lower ranks. Simultaneously he did promote Rhinelanders and move family members and friends from his native region to Livonia. The Livonian sources mention no less than four other Rutenbergs - probably nephews in the years between I 428 en I45 I in Livonia. Direct patronage being involved is furthermore clear in the case of the careers of Sweder and Johan van Reve from the surroundings of Hellendoorn near the Hanse town of Zwolle. Sweder acted as Vogt of Soneburg in I 427 , managed to acquire a seat in the 'Inner Council' as commander of Goldingen later on and was awarded the prestigious commandership of Riga in I 432. As such he would act as Vice-Master for Rutenberg during the latter's fateful journey of I 433. His brother Johan was a cleric who pursued an academic career. When he was delegated to the council-general of Basle with eight other doctores in the name of the university of Paris for the German nation, he was asked by the Grand Master to 
represent the Order there too. ${ }^{27}$ This was as a quid pro quo, for it had been thanks to the Order that he had been able to study in Paris. ${ }^{28}$ Rutenberg even made an attempt to have him named bishop of Oesel in $1432 .{ }^{29}$ This was not to be, but until I 438 Johan van Reve did go on to defend the general Order's interests at the council of Basle and in the interim at Florence. ${ }^{30}$

\section{The downfall of Matthias van Boningen}

Rutenberg's most significant protégé undoubtedly was Matthias van Boningen, from the area around Ootmarsum a few miles west of Bentheim. He first appears in historical records in I $43 \mathrm{I}$, when he, as commander of Doblen, was given a confidential assignment by Rutenberg. He had to bring the seals of the Livonian commanders to the Grand Master to affirm his alliance with the Lithuanian Grand Duke Switrigail. This alliance was intended to drive a wedge between Poland and a part of Lithuania. It tragically brought the Livonian branch much misfortune because her military campaigns had little success, with Switrigail offering nothing in return. In September I 43 I a Livonian army walked into a Polish ambush at the small river Nakel. This, by the way, proved fortunate for Boningen's career because he was not amongst the combatants. It allowed him to take the place of the captured commander of Marienburg and therefore gain access to the 'Inner Council'. His influence then grew further after the 1433 campaign by Rutenberg that had to be so prematurely cancelled, due to the illness of nearly every brother involved.

When Rutenberg died and a successor had to be chosen, Boningen was sought out by the Rhineland party to defend its candidate Franke Kerskorf with Grand Master Paul von Rusdorf. That Kerskorf ended up being elected, will not have improved Boningen's popularity amongst his Westphalian fellow brothers. At the time, however, this was of no concern to him and he enjoyed the patronage of Rusdorf and Kerskorf, so he could move on to the Vogtei of Wenden in November I 434. Because the above mentioned recruitment campaign in Utrecht started at

27 Liv-, Est- und Kurlandisches Urkundenbuch [further as: LivUB], [I. afd.], 12 vols., ed. G. von Bunge, e. a.; II. part., 3 vols., ed. L. Arbusow, Reval-Riga-Moscow 1853-1914 (reprint: Aalen 1967-1981), hier: vol. VIII, nr. 367 (1439, November 21).

28 This is proven by a letter - accompanied by an Oesel stallion, as a gift - in which Sweder renders the Grand Master thanks for his letter of recommendation, sent to the masters of the university of Paris; which letter had been asked for by the Master of Livonia (Rutenberg!): LivUB VIII, nr. 419.

29 LivUB VIII, nr. 562 (1432, February 28): letter to the Grand Master.

30 C. A. Lückerath, Paul von Rusdorf. Hochmeister des Deutschen Ordens (Quellen und Studien zur Geschichte des Deutschen Ordens15), Bonn-Bad Godesberg 1969, pp. 112, 117 ff, 179. 
precisely this time, it can be presumed that Boningen had taken the initiative to have it be organised.

The situation changed, however, after September I, I 435, when the new Master of Livonia, who in contrast to the Grand Master had stayed true to the alliance with Switrigail, suffered a crushing defeat against a Polish-Lithuanian force. Next to Kerskorf, almost all significant Rhineland 'Gebietiger' died in that action, meaning that overnight leadership of the Order in Livonia was returned to the Westphalians. They presented the Grand Master with but one candidate, their own: Heinrich Schüngel. Because of the emergency situation, but also because the Grand Master's position of power in Prussia was severely weakened and he did not dare intervene militarily, the Grand Master had to swear in their man after half a year.

This had consequences for Boningen. He managed to maintain a high position as Vogt of Jerwen for a short time, but was placed back in 1436 with an appointment as commander of Goldingen. His position, and with that, those of his protégés from the prince-bishopric of Utrecht, became especially precarious in the spring of 1438 when, following the death of the relatively moderate Schüngel, the fight for the office of Master broke out again with fervour. This time the Rhinelanders were far outnumbered. Boningen and another Rhinelander were dispatched to the Grand Master to support their candidate Heinrich von Notleben, who was a Thuringian by origin. Two Westphalians travelled with them to plead for the election of marshal Heinrich Vincke von Overberg. Despite the Westphalian ascendancy, Boningen seemed to have been successful, because at the end Rusdorf's choice indeed fell on Notleben. The Westphalians, however, did not accept this and decided to take the entire Livonian branch of the Order - the Rhinelanders included, who apparently gave way to the numerical superiority to submit the issue of candidacy to a large chapter, and heed Heinrich Vincke as stadholder in the meantime. This meant the Livonian Order turning away from Grand Master Paul von Rusdorf. Boningen, functioning as his partisan, kept him continually up to date about ongoing developments during this time, and advised him on how best to deal with the rebels. ${ }^{31}$

The tide kept turning against Rusdorf and Boningen, however. The hostility of the mood is evidenced by Boningen's letter to Rusdorf from July I 438 , in which he remarks that if the land marshal (Vincke) and his ilk would succeed in maintaining their momentum, he himself had better not stay in the country

\footnotetext{
31 Lückerath (as n. 30), p. 179.
} 
lest he end up imprisoned. ${ }^{32}$ It would have been for the same reason that he requested the Grand Master via the commander of Elbing (Prussia) to transfer his protégé Wolter van Almelo as soon as possible to Prussia. Boningen, and Rusdorf too, could offer no opportunities for Utrecht brothers in Livonia anymore. In this light, dr. Johan van Reve's departure is very understandable. In I 438 he cancelled his tenure in the Order, returned to the west and became provost of Oldenzaal in the eastern Netherlands.

As opposed to several of his party members, Matthias van Boningen did not end up in jail. He did, however, have to give up his post of commander of Goldingen immediately in August, lost his seat in the 'Inner Council' and was fobbed with the much less important Vogtei of Rositten. In October he, as well as the three remaining Rhineland 'Gebietiger', chose to make the best of a bad bargain and swore fealty to stadholder Heinrich Vincke; this on the condition that he would not be punished further. Meanwhile the Order had come to a full split between the Grand Master on the one hand and the German Master and the Livonian stadholder on the other. The result of this schism for Livonia was that Heinrich Vincke was promoted to Livonian Master by the German Master who acted on his own, after first having gained support of the Livonian prelates and knighthood. Rusdorf eventually saw no more chance to overcome the resistance to his politics and his person, and abdicated as Grand Master on January 2, I 44 I.

With that, Boningen had lost all support. In the next years he was continually degraded in rank, against which he tried to resist by asking lords in his territory of origin for intervention. In 1447 the count of Bentheim and the bishop of Utrecht, for instance, wrote letters to the Grand Master in Prussia, requesting that it be accomplished with the Master of Livonia that Matthias van Boningen, of whom they had heard tell that he had been humiliated with an insignificant post (Windau), was promoted in office once again, or, if that were not possible, that he at least could maintain the commandership of Windau. Boningen, after all, was born 'from the best and oldest of knighthood' and fully deserved a considerable and honourable office. ${ }^{33}$ Such letters of recommendation mattered nothing however, as is shown by two other, similar written appeals from 1450 , by the bishop of Utre-

32 [...] wente [Vincke c. s.] see sin my besunderen [...] tomale hardt, unde mogen uns nicht liden, umbe deswillen dat ich ene to Marienborgh in eren saken so hard en tegen was; und vorchte, beholden see eeren wilen, dar Got vorsie, so worpen se my ower in eynen torn, LivUB IX, nr. 303 (1438, July16).

33 The Count of Bentheim informs the Grand Master that Matthias and his parents have rendered him a lot of services: [...] und syne aelderen und mage unse nabuer geboren syn und uns menegen deynst gedaen hebben [...] und uns seer fruntlick mit en bewant ys [...], LivUB X, nr. 302 (1447, March 12); see also the answer of the Grand Master: LivUB X, nr. 322. 
cht and the duke of Guelders, asking the Grand Master to supply Boningen with a post again. ${ }^{34}$ It was a waste of paper and ink. Matthias van Boningen was sidelined and turned down. In 145 I we encounter him as a brother without office in the convent of Fellin. The men he had brought with him to Livonia from his own region must have been victims as well of his radical pro-grand masterly course. Since then, they barely got any offices offered to them. This was the reason that not only office-less brothers like Jan van Enghuzen, but also one of the few Utrecht 'Gebietiger' like Willem van Hinderstein, left Livonia in the fifties to try and acquire a place in their native bailiwick.

Knight brothers from Guelders, Limburg, Brabant and Loon, too, suffered from Westphalian domination. Hindrik van Iseren still functioned as commander of Talkhof in I 448, but turns out to have been degraded to simple knight brother in Oberpalen by I 45 I. The same goes for Johan van Eyl. In I45 I he stayed in Pernau as a brother without a post, whilst in the years of I 443-I 444 he had administered an important district as Vogt of Wesenberg. Nevertheless, the number of brothers from Guelders decreased less severely than the Utrecht ones. When tracing the position of these brothers from the south-eastern and southern Netherlands in the Livonian hierarchy of the sixteenth century, it turns out that most of them never got beyond a house office. No-one made it to member of the 'Inner Council', marshall or Master. The only exception concerns Jasper van Munster, who would really climb up the ranks and even succeeded to become marshal and candidate Master. He was not from the South but from the North but he could boast Westphalian ancestors and relatives. Of the other 23 only four managed to attain the position of 'Gebietiger' (as commander, advocat, sheriff or 'Hauptman'); nine brothers are attested as house commander, Kompan or Schenk; of the other ones nothing more is known than that they were office-less knights. Not many chances were thus offered to these people.

This is fully congruent with Milizer and Neitmann's conclusions, who emphasize the strong dominance of the Westphalians and - within this group - the growing preponderance of the men from the county of Mark within the upper ranks of the Livonian branch of the Order in the sixteenth century. Militzer, who counted I 68 names for the period of I 536- I 562 (subdivided into five Livonian masters, 69 'Gebietiger' including land marshals, Vögte and 'Hauptmänner', 5 I house officials and 43 post-less brothers), of whom roughly $60 \%$ originated from Westphalia (including the North-German lowlands) and $40 \%$ from the Rhineland, established that the Westphalians provided five masters, 48 out of 69

\footnotetext{
34 LivUB XI, nrs. 30, 32 (1450, April 21 and 26).
} 
'Gebietiger' (= 70\%), 25 out of 5 I house commanders and the like $(=49 \%)$ and 43 of the post-less brothers $(=45 \%)$.

\section{TO CONCLUDE: THE SOCIAL ORIGIN OF THE BRETHREN, AND} THE REGIONAL COHESION BETWEEN THEM

It is not easy to assess what brought about the growing animosity between the opposing groups. The language cannot have played an important role. Brethren from the Lower and Middle Rhine areas could perfectly well understand the Westphalians and vice versa. And as for noble families in the northeast part of the bishopric of Utrecht on the one side and the Westphalian Münsterland on the other, a lot of them were interrelated, as is shown in the person of Sweder Cobbing, who was accepted without any problems as land commander of the bailiwick of Westphalia, which had its main convent in Münster. For that matter, there was much more logic in the party contrasts in Prussia, where the Westphalians and Rhinelanders found themselves united against the men from High Germany, who spoke a different tongue. As for the Rhinelanders, it does not at all look as if their regions of origin constituted an entity on itself. There can hardly have been kinship relations between the men from the Northwest, the middle Rhine area and Hessia for instance. Looking at all the territories involved we can only say that some way or another the 'Rhinelanders' made up a broad non-Westphalian rest category. The members then might have tended to seek each other's help against exclusion by a Westphalian core group.

Furthermore, we must realise that the social group from which men were recruited was changing gradually after 1350 . In the period of consolidation of the Order's power, the Livonian branch recruited its lay members in growing numbers from the ministeriales class. In this context, Neitmann speaks of a highly homogeneous group. Amongst the eleven Masters of Livonia in the period of I 3 I O-1 410 only one was a brother-knight whose origin was of the free nobility. The rest either came from the ministerialty or had a similar background. The seventeen Masters from the period of I 4 I I I 562 all came from the lesser nobility. Within that lesser nobility of course there were large internal differences. There were poor knightly families who held no direct relation to their territorial lord and even locally held no offices; who lived off the income of one or two farms and were barely able to supply their sons with a saddle and a suit of armour. There were those, too, that held extensive property complexes of feudal tenure and goods in various territories; whose sons occupied lucrative administrative posts allowing them to earn large sums of money. It is clear as day, that such differences in standing, wealth 
and power had a great influence on the careers of the brethren of the Order. This is emphasized by Sonja Neitmann in her analysis of social antecedents of the office-less brothers of I 45 I, making up some $80 \%$ of the whole at that time. These office-less-ones turn out to have been from insignificant families far more often than the brothers that rose to the offices. ${ }^{35}$

This however, must have been the same for the Westphalians and the Rhinelanders including the brethren from the Low Countries. What may have been a decisive factor is that the Order's structures in the west, that is the bailiwicks, apparently ceased to play a role in the recruitment after the second half of the fifteenth century. Even the bailiwick of Westphalia failed to be an intermediary station by then. Since the important commanders in Livonia tended to become semi-autonomous rulers themselves, along with the Master and the marshall, they each also exerted a sort of patronage, by getting relatives as candidate order knights to Livonia. Recruitment was thus informally decentralised. Which meant that replacement was in the hands of all important office-holders. The most of which were Westphalians and men from the Mark already. In other words, once the predominance was established via Westphalian masters it developed into a self reinforcing process. A process that hardly left offered any perspectives for men from the Low Countries in the sixteenth century.

${ }^{35}$ Neitmann (as n. 3), pp. 619-620. 


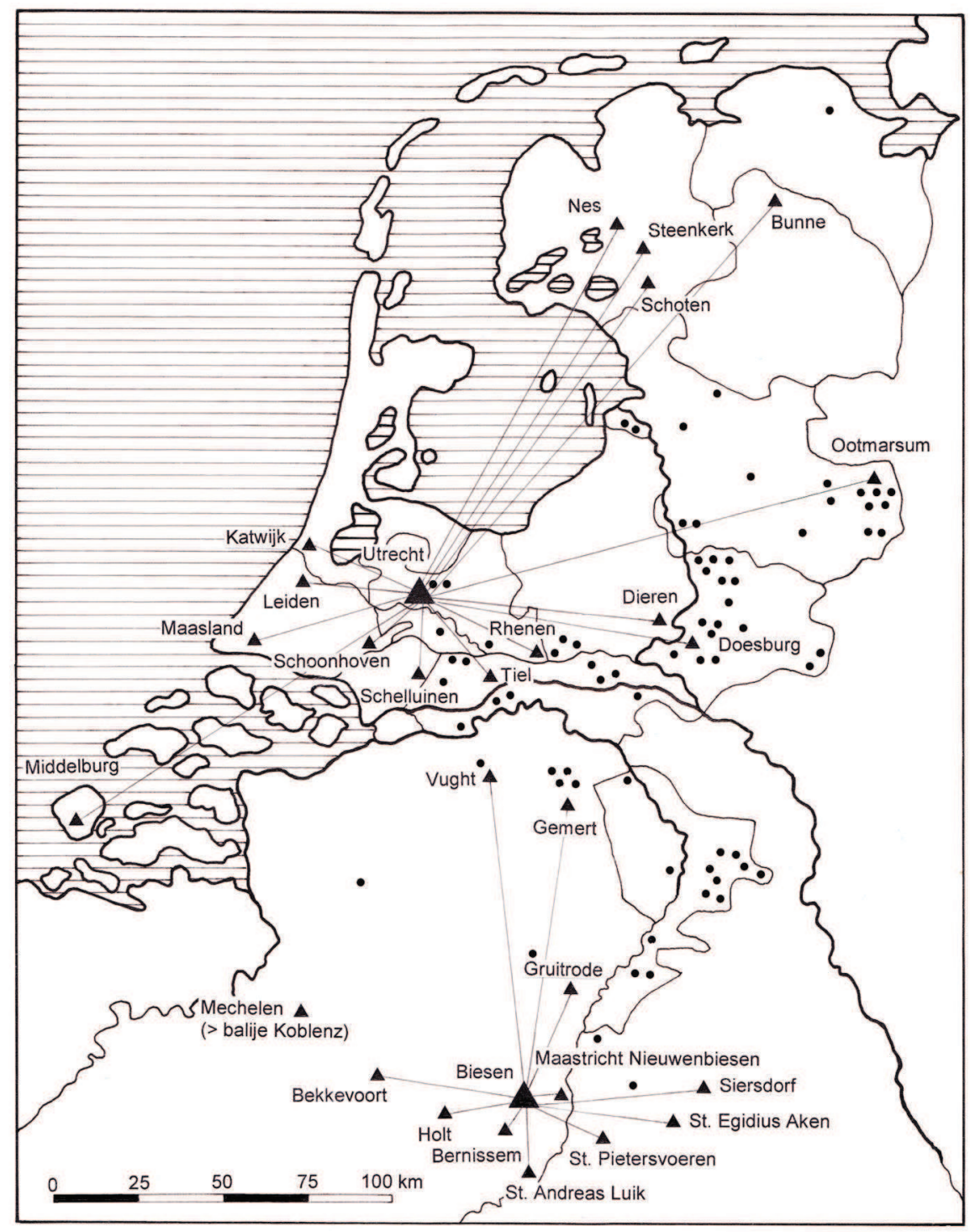

Map: The regional origin of the 'Dutch' brethren in the Livonian branch of the Teutonic Order (1300-1562) 


\section{SOURCES AND LiterATURE}

van Doorninck Jan I., edit. Tijdrekenkundig register op het oud provinciaal archief van Overijssel, I225-I496, aanhangsel. Zwolle: De Erven Tijl, i 874 .

de Geer tot Oudegein, Jan J., edit. Archieven der Ridderlijke Duitsche Orde, balie van Utrecht. 2 vols. Utrecht: Kemink en zoon, i 87 I.

Hildebrand, Hermann., edit. Liv-, Est- und Kurlandisches Urkundenbuch [I. afd.]. vol. VIII: I429 Mai - I435. Riga, Moskau: Heinrich Laakmann, I 885 (reprint: Aalen: Scientia Verlag, I 974)

Joachim, Ernst. Hubatsch, Walter., edit. Regesta Historico-Diplomatica Ordinis S. Mariae Theutonicorum II98-1525. vols. I-2. Göttingen: Vandenhoeck \& Ruprecht, I948$-1973$.

Benninghoven, Friedrich. "Die Burgen als Grundpfeiler des spätmittelalterlichen Wehrwesens im preußisch livländischen Deutschordensstaat." In Die Burgen im Deutschen Sprachraum (part I), edited by Hans Patze, 565-60 I. Sigmaringen I 976.

Benninghoven, Friedrich. "Zur Zahl und Standortverteilung der Brüder des Deutschen Ordens in den Balleien um I 400." Preußenland 26 (1988): I-20

Christiansen, Eric. The Northern Crusades. The Baltic and the Catholic frontier II00-1525. London: The Macmillan Press, I980.

Jähnig, Bernhart. Verfassung und Verwaltung des Deutschen Ordens und seiner Herrschaft in Livland. Berlin: LIT-Verlag, 20 I I.

Lückerath, Carl A. Paul von Rusdorf. Hochmeister des Deutschen Ordens. Bonn, Bad Godesberg: Verlag Wissenschaftliches Archiv, I 969.

Merckens, Otto. "Die Vorfahren der Irmgard von Schönau (Schoenauwen), Gemahlin des Johann Schenck von Nydeggen.” Jülich-Bergische Geschichtsblätter I I (1934): 17-22, $43-48$.

Militzer, Klaus. "Die Ritterbrüder im livländischen Zweig des Deutschen Ordens. Eine Einführung in die Möglichkeiten und Grenzen der Auswertung des Ritterbruderkatalogs." In Ritterbrüder im livländischen Zweig des Deutschen Ordens, edited by L. Fenske, K. Militzer, I I-70. Köln, Weimar, Wien: Böhlau, I 993.

Neitmann, Sonja. Von der Grafschaft Mark nach Livland. Ritterbrüder aus Westfalen im livländischen Deutschen Orden. Köln, Weimar, Wien: Böhlau, I 993.

Ritterbrüder im livländischen Zweig des Deutschen Ordens, edited by L. Fenske, K. Militzer. Köln, Weimar, Wien: Böhlau, I 993.

Van Schilfgaarde, Anthonie P. "Het adellijk geslacht Van Rossem." De Nederlandsche Leeuw 70 (1953): I 34-I 49.

Stapel, Rombert. ““'Onder dese ridderen zijn oec papen”. Priesterbroeders in de balije Utrecht van de Duitse Orde (1350-1600)." Jaarboek voor Middeleeuwse Geschiedenis I I (2008): 205-248. 


\section{Abstract \\ The knight brothers from the Low Countries in the conflict between the Westphalians and the Rhinelanders in the Livonian branch of the Teutonic Order}

In the fifteenth century the Livonian branch of the Teutonic Order was internally divided by a long-lasting conflict between two groups of knight brethren, the Westphalians and the Rhinelanders, who were united according to regional origin. They each strived to control the most important offices, though their discord indirectly also concerned the political course of the Order state. The central question in this paper is how the brethren from the Netherlands - not clearly being tied to Westphalia or the Rhineland - fared in this strife for predominance within Livonia. It is shown that the brethren from the Low Countries got access to central positions by joining the Rhineland group, who - with support of Grand Master Paul von Rusdorf in Prussia - gained the upper hand for some time, especially after one of them, Cisse van den Rutenberg, was appointed Livonian Master in 1424 The result was that the 'Dutch' could increase their number, counting for about one sixth of the Livonian knights around 1435. Looking more closely at the background of the Rhinelanders we have to conclude that these, originating from regions at relatively great distance from each other, did not constitute a cohesive party but must have made up a broad non-Westphalian rest category. The members might have tended to seek each other's help against exclusion by a Westphalian core group. When the Westphalians succeeded in regaining the leading position in 1438 , they reinforced their grip on the recruitment and advancement of the knight brethren. For the 'Dutch', this meant that they lost all career perspectives, with the result that their number decreased greatly after 1450 . 


\title{
○RDINES MILITARES COLLOQUIA TORUNENSIA HISTORICA Yearbook for the Study of the Military Orders
}

\author{
vol. XX (2015)
}


EDITORIAL BOARD

Roman Czaja, Editor in Chief, Nicolaus Copernicus University Toruń

Jürgen Sarnowsky, Editor in Chief, University of Hamburg

Jochen Burgtorf, California State University

Sylvain Gouguenheim, Ecole Normale Supérieure Lettres et Sciences Humaines de Lyon Hubert Houben, Università del Salento Lecce

Alan V. Murray, University of Leeds

Krzysztof Kwiatkowski, Assistant Editor, Nicolaus Copernicus University Toruń

REVIEWERS:

Udo Arnold, Rheinische Friedrich-Wilhelms-Universität Bonn (retired)

Jochen Burgtorf, Department of History, California State University

Marian Dygo, Instytut Historyczny, Uniwesytet Warszawski Alan Forey, Durham University (retired)

Mateusz Goliński, Instytut Historyczny, Uniwersytet Wrocławski

Sylvain Gouguenheim, Ecole Normale Supérieure Lettres et Sciences Humaines de Lyon

Dieter Heckmann, Geheimes Staatsarchiv Preußischer Kulturbesitz, Berlin-Dahlem

Heinz-Dieter Heimann, Universität Potsdam (retired)

Hubert Houben, Dipartimento di Storia, Società e Studi sull'uomo, Universita del Salento, Lecce

Sławomir Jóźwiak, Instytut Historii i Archiwistyki, Uniwersytet Mikołaja Kopernika, Toruń

Tomasz Jurek, Instytut Historii im. Tadeusza Manteuffla Polskiej Akademii Nauk, Warszawa

Waldemar Könighaus, Akademie der Wissenschaften zu Göttingen

Ilgvars Misāns, Faculty of History and Philosophy, University of Latvia, Riga Helen Nicholson, History Department, Cardiff University

Jürgen Sarnowsky, Fakultät für Geisteswissenschaften, Universität Hamburg

Kristjan Toomaspoeg, Beni Culturali Department, Università Del Salento, Lecce

Address of Editorial OfFice:

Instytut Historii i Archiwistyki UMK, ul. Władysława Bojarskiego 1

87-100 Toruń

e-mail: rc@umk.p

juergen.sarnowsky@uni-hamburg.de

Subscriptions orders shoud be addressed to:

$$
\text { books@umk.pl }
$$

creative

Czasopismo jest wydawane na zasadach licencji niewyłącznej

Creative Commons i dystrybuowane w wersii elektronicznej

Open Access przez Akadmicką Platformę Czasopism (c) (1)

www.apcz.pl

Printed in Poland

(C) Copyright by Uniwersytet Mikołaja Kopernika w Toruniu and Towarzystwo Naukowe w Toruniu Toruń 2015

ISSN $0867-2008$

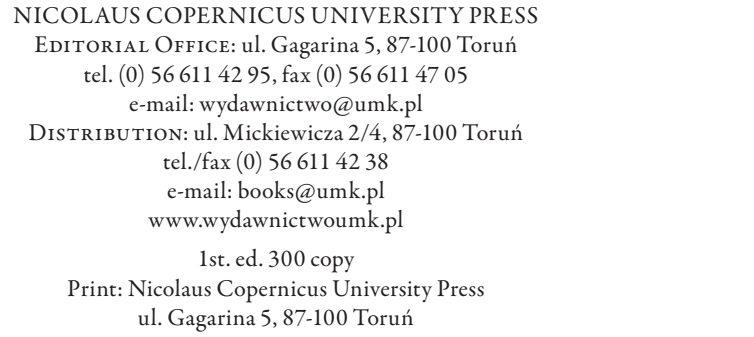




\section{CONTENTS}

\section{STUDIES AND ARTICLES FROM THE $17^{\text {TH }}$ ORDINES MILITARES CONFERENCE}

Alan V.Murray (Leeds)

The Grand Designs of Gilbert of Assailly. The Order of the Hospital in the Projected Conquest of Egypt by King Amalric of Jerusalem (I 168 - I 169 ) ...

Karl Borchardt (München)

Die Templer an der römischen Kurie im I 3. Jahrhundert: ein Netzwerk? ......

Marie-Luise Favreau-Lilie (Berlin)

Der Deutsche Orden in Norditalien (1 3. Jh.). Über die Grenzen der

"Netzwerkforschung"

Christian Gablbeck (Berlin)

Adlige Netzwerke in der mittelalterlichen Ballei Brandenburg des

Johanniterordens

Maria Starnawska (Częstochowa)

Karrieren innerhalb des Johanniterordens (in den schlesischen ländlichen Kommenden des böhmischen Priorats) als Bestandteil familierer Strategien des Rittertums

Johannes A. Mol (Leiden)

The knight brothers from the Low Countries in the conflict between the Westphalians and the Rhinelanders in the Livonian branch of the Teutonic Order

Bernhard Demel (Wien)

Zur Reichspolitik des livländischen Ordenszweiges in den Jahren I $52 \mathrm{I}$ bis I56I/I 562 


\section{OTHER STUDIES}

\section{Loüc Chollet (Neuchâtel)}

Croisade ou évangélisation? La polémique contre les Chevaliers

Teutoniques à l'aune des témoignages des voyageurs français de la fin du Moyen-Âge

Anette Löffler (Frankfurt/Main)

Swester und Oberste - ein Brevier für einen Schwesternkonvent des

Deutschen Ordens

Stawomir Jóźwiak (Toruń), Janusz Trupinda (Gdańsk)

Das Amt des „Bauleiters“ (magister lapidum; magister laterum;

steinmeister; czygelmeyster; muwermeister) im Deutschordensstaat im

I 4. Jh. und in der ersten Hälfte des I 5 . Jh.

\section{BOOK REVIEWS AND BOOK NOTES}

Aleksander G. Pluskowski, The Archaeology of the Prussian Crusade: Holy War and Colonisation (by Seweryn Szczepanski)

Marc Sgonina, Die Johanniterballei Westfalen. Unter besonderer Berücksichtigung der Lebensformen der Zentralkommende Steinfurt und ihrer Membra (by Christian Gablbeck)

Jerusalem in the North: Denmark and the Baltic Crusades, II0o-I522, eds. Ane Bysted, Carsten V. Jensen, Kurt S. Jensen, John Lind (by Roman Czaja)

Alain Demurger, La persécution des Templiers. Journal (1307-1314)

(by Magdalena Satora)

Tous les diables d'enfer. Rélations du siège de Rhodes par les Ottomans en I480, ed. Jean-Bernard de Vaivre, Laurent Vissière (by Jürgen Sarnowsky)

Generalprobe Burzenland. Neue Forschungen zur Geschichte des Deutschen Ordens in Siebenbürgen und im Banat, hrsg. v. Konrad Gündisch

(by Krzysztof Kwiatkowski)

Die Hochmeister des Deutschen Ordens IIgo-2012, hrsg. v. Udo Arnold

(by Krzysztof Kwiatkowski)

Beztawki - ocalić od zniszczenia. Wyniki prac interdyscyplinarnych prowadzonych w latach 2008-20II, red. Arkadiusz Koperkiewicz (by Krzysztof Kwiatkowski)

Das „virtuelle Archiv des Deutschen Ordens“, hrsg. v. Maria M. Rückert

(by Radostaw Biskup) 